\title{
Die $Q^{1}$ gemeenskap as een van die grondtipes van die kerk in die Nuwe Testament
}

\author{
Gert J Malan (Mosselbaai) ${ }^{1}$ \\ Navorsingsassosiaat: Departement Nuwe-Testamentiese Wetenskap \\ Universiteit van Pretoria
}

\begin{abstract}
The community of $\mathbf{Q}^{1}$ as prototype of the church in the New Testament

The New Testament bears witness to a wide variety of communities, representing a spectrum of ideas and teachings about Jesus and the meaning of his life. In this article these communities are regarded as prototypes of churches which have a certain bearing on churches and their teachings today. The article aims to investigate communities behind $Q$ as prototypes. It focuses on the community responsible for the first layer of $Q$ material, with the intention of asking whether they might have constituted such a prototype of the church. To achieve this, the "kingdom of God" is studied as their symbolic universe. The result is that, while the $Q^{1}$ community cannot be called "Christian" or "church" in the strict sense of the word, it challenges the church by representing the kingdom of God in a world of uncertainty, danger, and misuse of power.
\end{abstract}

\section{INLEIDING}

Bestudering van $Q$ het die gedagte versterk dat die Jesusbeweging verantwoordelik vir $Q$, nie Christene was nie: hulle het Jesus nie as Messias beskou nie, nie 'n spesiale groep opgeleide dissipels as hulle leiers erken nie, nie gedink Jesus het na Jerusalem gereis om die tempel te reinig of die Joodse godsdiens te hervorm nie, nie Jesus se dood as 'n ongewone goddelike gebeure beskou nie en ook nie Jesus se leringe nagevolg ten einde verlos te word nie (Mack 1993:48).

\footnotetext{
${ }^{1} \mathrm{Dr}$ G J Malan neem deel aan die navorsingsprojek "Bybelse Teologie en Hermeneutiek" onder leiding van dr Andries G van Aarde, emeritusprofessor in die Departement NuweTestamentiese Wetenskap, Fakulteit Teologie, Universiteit van Pretoria.
} 


\section{Die $Q^{1}$ gemeenskap as een van die grondtipes van die kerk in die Nuwe Testament}

Die vraag aan die orde in hierdie studie is of die vroeë $Q^{1}$ gemeenskap, wat die eerste laag van $Q^{1}$ daargestel het, nie tog as grondtipe van die kerk beskou kan word nie. In hierdie verband word grootliks gebruik gemaak van Burton Mack (1993) se rekonstruksie van die $Q^{1}$ gemeenskap. Die ondersoek sal veral aandag gee aan die term "koninkryk van God" (basileia tou theou) as moontlike aanduiding van "Christelike" denke, of anders gestel: aanduiding van die $Q^{1}$ gemeenskap se simboliese universum (vgl hier onder), aangesien dit ook die enigste term in $Q^{1}$ is waarmee die geloofsgemeenskap aangedui word. Die term basileia tou theou is van groot belang in $Q^{1}$. Kloppenborg (1999:242) stel dit so: "With some justification this stratum of $Q$ could be termed 'the radical wisdom of the kingdom of God".

\section{DIE KERKE AGTER DIE NUWE-TESTAMENTIESE TEKSTE AS GRONDTIPES}

Die verskeidenheid van die Nuwe-Testamentiese dokumente bevestig dat daar nie gepraat behoort te word van die kerk in of die kerkbegrip van die Nuwe Testament nie. Daar is eerder sprake van 'n verskeidenheid van geloofsgemeenskappe wat verskuil lê agter die Nuwe-Testamentiese dokumente, elk met hulle eie kenmerkende persepsies oor kerkwees. Daar het selfs by die verskillende geloofsgemeenskappe ontwikkelings plaasgevind met betrekking tot hulle persepsies van kerkwees, na mate die paroesie uitgebly het, omstandighede verander het en ander invloede op hulle ingewerk het (Pelser 1995:645-676).

Käsemann noem hierdie geloofsgemeenskappe eerder ekklesiologiese grondtipes as wat hy dit kerk noem. Hy stel dit so: "Das Neue Testament schenkt uns keine ecclesiologia perennis, bietet uns jedoch ekklesiologische Grundtypen"(Käsemann 1964:262). Hierdie geloofsgemeenskappe, as ekklesiologiese grondtipes, se variasie in die kerugma is uitdrukking van die feit dat daar binne die oer-Christendom 'n verskeidenheid in belydenis naas mekaar bestaan het, op mekaar gevolg het, met mekaar in verband gestaan het en ook teen mekaar afgegrens het (Käsemann [1951] 1960:221). Dit beteken dat daar 'n verskeidenheid persepsies oor Jesus en die betekenis van sy lewe was, wat in hierdie geloofsgemeenskappe geleef het en wat deur die onderskeie dokumente beklemtoon is en selfs teen ander afgegrens is.

Wanneer daar met hierdie werklikheid rekening gehou word, word die studie oor die kerkbegrip en die aanvanklike verskyningsvorme van die kerk, gedoen aan die hand van die onderskeie Nuwe-Testamentiese dokumente en korpusse, byvoorbeeld Paulus, Markus, Lukas-Handelinge, Openbaring, Hebreërs, Jakobus en so meer (vgl bv Bultmann 1980; Kümmel 1980; Lohse 1979). $Q$ word as bron vir die evangelies hanteer word en verskillende Sitze 
im Leben word voorgestel word vir die onderskeie tipes logia, soos Bultmann (1963) doen in sy Geschichte der Synoptische Tradition. Q is beskou as 'n uitbreiding van die aanvanklike logia tradisie, wat gegroei het deur die toevoeging van populêre wysheid, spreekwoorde, profesie en reëls met die oog op paranese. So verstaan, was $Q$ nie die sentrum van die verkondiging nie, maar 'n supplement (vgl ook Kloppenborg 1999:19-22). Die Qgemeenskap(pe) se eiesoortige verstaan van Jesus se boodskap bly in die slag en daarmee hulle eie aard as gemeenskap(pe).

Dit kan meebring dat die gemeenskap(pe) wat die Q-bron tot stand gebring het, met hulle eiesoortige verstaan van Jesus en hulleself as Jesusgroep(e), in so 'n geval nie beskryf word of beskou word as moontlike "grondtipe(s)" van die kerk nie. So meen Bultmann (1980:1-2) dat Jesus se eie verkondiging die vooronderstelling vir die teologie van die Nuwe Testament is, en nie deel daarvan vorm nie. Maak hy daarmee $Q$ as naaste bron aan egte Jesuswoorde onbewustelik ook tot vooronderstelling? Christelike geloof bestaan volgens hom eers sedert die Christelike kerugma, wat Jesus as God se eskatologiese heilsdaad verkondig, dit wil sê Jesus as gekruisig en verrese. Hieroor sê Bultmann (1980:2) "Das geschieht erst im Urgemeinde, nicht schon in der Verkündigung des geschichtlichen Jesus, wenngleich die Gemeinde in den Bericht über diese vielfach Motive ihres eigenen Kerygmas eingetragen hat". Teologie begin vir hom eers met "Christelike verkondiging". Dis hierdie aspek wat die gemeenskap as "Gemeinde" konstitueer.

Vir die vroeë kerk was Jesus meer as profeet en leermeester. Jesus was vir hulle Messias, die komende "Menseseun". Die vroeë kerk het volgens Bultmann (1980:35-37) nie net Jesus se boodskap verkondig nie. Jesus self het as persoon die inhoud van die kerk se verkondiging geword. Volgens hierdie verstaan sal $Q^{1}$ nie verkondiging wees nie en die gemeenskap daaragter nie 'n gemeente wees nie.

So 'n siening kan meebring dat mense wat vandag soortgelyke gedagtes oor Jesus en die betekenis van sy lewe huldig as die Qgemeenskap(pe), dalk deur sommige as on-Nuwe-Testamenties, illegitiem en onaanvaarbaar beskou kan word. Is so 'n beoordeling geregverdig? Pelser (1995:674) roer juis teen die einde van sy artikel oor die kerk in die Nuwe Testament die omstrede vraag aan, naamlik oor watter die "mees aanvaarbare" Nuwe-Testamentiese kerkmodelle sou wees. Hy meen dat bepaalde Nuwe-Testamentiese persepsies tog 'n getrouer weergawe as ander blyk te wees van hoe die kerk homself moet verstaan in die lig van die Christusgebeure. Die vraag is of en in watter mate die Q-gemeenskap(pe) as 'n moontlike legitieme model van 'n geloofsgemeenskap en as 'n aanvaarbare grondtipe van die kerk, naas ander in die Nuwe Testament beskou kan word, of nie. 
Die werklikheid is dat $Q$ tot op hede nie gevind is nie, en moontlik vir altyd vir ons verlore is. Dit kan veronderstel dat die Q-gemeenskap(pe) om een of ander rede tot 'n einde gekom het, hetsy byvoorbeeld deur assimilasie met ander groepe, of verkettering en ostrasering. Aan die ander kant kan dit bloot wees dat $Q$, wat sonder die "biografiese" raamwerk oorgelewer is, gewoon vanweë die hoë koste van skryfmateriaal, in onbruik geraak het omdat die "vollediger" evangelies waarin dit opgeneem is, algaande verkies is. So kon die Q-gemeenskap(pe) daaragter gaandeweg met ander groepe saamgesmelt het of andersins as afwykend beskou gewees het of irrelevant geword het.

Hoe dit ook al sy, die bestaan van so 'n geloofsgemeenskap kan nie weg geredeneer word nie, selfs nie al sou dit as afwykend beskou gewees het of tot niet gegaan het nie. Die moontlikheid wat dit veronderstel, is dat ook hierdie geloofsgemeenskap op 'n aanvanklike stadium wel nie as afwykend beskou is nie, en hier en daar selfs as die enigste vorm of grondtipe van die kerk gedien het en dat hulle aanhangers selfs 'n meerderheid kon gevorm het in 'n gebied - 'n meerderheid wat selfs met "spot" kon neersien op die "ortodoksie" van ander groepe (Bauer 1972:xxii).

Oor hierdie Q-gemeenskap(pe) het geleerdes aanvanklik gepraat as die vroegste vorm van Christelike gemeenskap. Sommige het selfs die term "kerk" gebruik. In Q verwys word egter nie verwys na die dood en opstanding van Jesus nie; $Q$ praat nie oor Jesus as die Christus nie en bevat geen opdrag van Jesus aan Petrus en die ander dissipels om Jesus se sending voort te sit en bekeerlinge deur die doop in te lyf nie (Mack 1993:42-43). Die term "koninkryk van God" (basileia tou theou) is egter die term waarmee hierdie geloofsgemeenskap(pe), reeds in die vroegste laag van $Q$, na hulleself verwys het. Dit is die term waarmee hulle hulle identiteit aandui en die kwaliteit en aard van hulle onderlinge verhoudings en hulle verhouding met God, wat deur Jesus se optrede verwesenlik is. Vervolgens gaan gekyk word hoe die term "koninkryk van God" (basileia tou theou) in die tekste funksioneer.

\section{DIE $Q^{1}$ TEKSTE WAAR DIE BEGRIP “BASILEIA TOU THEOU' VOORKOM}

Die koninkryk van God word in sewe $Q^{1}$ tekste vermeld naamlik (Mack 1993:124) (notasie volgens Mack se stelsel):

- Gelukkig is die armes, want aan hulle behoort die koninkryk van God (QS 8). 
- Niemand wat sy hand aan die ploeg slaan en terugkyk, is geskik vir die koninkryk van God nie (QS 19).

- Wanneer julle 'n dorp binnegaan en hulle verwelkom julle, eet wat vir julle voorgesit word en versorg die siekes, en sê: "Die koninkryk van God het naby julle gekom" (QS 20).

- Maar as julle 'n dorp binnegaan en hulle verwelkom julle nie, sê: "Desnieteenstaande, God se koninkryk het na julle toe gekom" (QS 20).

- Wanneer julle bid, sê: "Vader ..., mag u koninkryk kom, gee ons elke dag se brood" (QS 26).

- Maak seker van sy heerskappy oor julle, en ook hierdie dinge sal julle s'n wees (QS 39).

- Waarmee kan God se koninkryk vergelyk word? Dit is soos 'n mosterdsaadjie ... Dit is soos suurdeeg wat 'n vrou versteek in drie mate meel (QS46).

Buiten in die geval van die laaste stelling, waar daar sprake is van natuurlike groei, lyk dit asof die betekenis van basileia tou theou gewoon aanvaar word en gekoppel word aan iets uit die gewone menslike leefwêreld. Basileia tou theou verteenwoordig iets wat bereik kan word, iets wat kontrasteer met die konvensionele, iets wat ' $n$ verandering van gesindheid verg of gedrag wat ' $n$ nuwe visie waardig is. Te midde van gewone menslike interaksie kan die basileia tou theou aangekondig, begeer, bevestig opgeëis of aangedui word. Die verbintenis tussen die heerskappy van God en die patroon van $Q^{1}$ se kontra-kulturele gebruike is baie sterk. Die $Q^{1}$ groep het in hierdie stadium begin afsien van optrede in die publieke arena, vanweë verwerping in die openbare sfeer. Hulle het hulle sending verder uitgevoer deur te reis en tuis te gaan by eendersdenkendes wat in huise vergader het, of aan huis by vreemdelinge. Dit is hier waar hulle die koninkryk van God aangekondig het en waar hulle gehoop het om gasvry ontvang te word (Mack 1993:129).

Dit is opmerklik dat nie een van die $Q^{1}$ tekste verwys na 'n apokaliptiese wêreldbeeld nie en ook nie die apokaliptiese wêreldbeeld as verwysingsraamwerk gebruik ten einde die term te verduidelik nie (Kloppenborg 1999:244-245, 322; Mack 1993:128). Dit dui aan dat die $Q^{1}$ groep nie die apokaliptiese wêreldbeeld as simboliese universum aanvaar het nie, waarbinne die koninkryk van God gelegitimeer word nie. Die koninkryk van God is die simboliese universum wat die groep se sosiale bestaan en optrede legitimeer. God se koninkryk was die perfekte sfeer, die simboliese universum waarin die sosiale wêreld sy verlenging gevind het (Van Aarde 2001:43). 


\section{DIE BETEKENISVELDE EN BETEKENISMOONTLIKHEDE VAN BASILEIA TOU THEOU}

Die betekenisvelde van basileia is die gebiede van regeringsadministrasie en regering. In die eerste geval is die betekenismoontlikheid van basileia 'n gebied of distrik wat deur 'n koning regeer word, naamlik 'n koninkryk (Louw \& Nida 1993a:44; Louw \& Nida 1993b:16). In die tweede geval dui basileia die heerskappy van 'n koning aan, wat impliseer dat hy volkome gesag uitoefen en ook die mag het om die reg om te regeer aan sy seun of naby bloedverwant oor te dra (Louw \& Nida 1993a:44; Louw \& Nida 1993b:479).

Theios val in die semantiese veld van bo-natuurlike wesens en magte. Die betekenismoontlikhede van theios is as volg: God, die een oppermagtige bo-natuurlike wese wat skepper en onderhouer is van die heelal (Louw \& Nida 1993a:118; Louw \& Nida 1993b:137). Daarbenewens ook 'n god, een van die vele verskillende bo-natuurlike wesens wat beskou word om gesag of beheer uit te oefen oor een of ander aspek van die heelal of menslike gedrag (Louw \& Nida 1993a:118; Louw \& Nida 1993b:143). Die kombinasie basileia tou theou kan die volgende betekenismoontlikhede hê, afhangende van die konteks waarin dit gebruik word: die gebied waaroor God/'n god regeer, of die heerskappy van God/'n god.

Dit is verder belangrik om na die historiese en kulturele konteks te kyk waarin die term ten tye van die daarstelling van $Q^{1}$ aangewend is. Die term basileia tou theou sou volgens Mack (1993:125) nie vreemd op die oor geval het in die Grieks-Romeinse tydperk nie. Die twee oorheersende modelle vir gesprekke oor sosiale sake, was die van die stadstaat (polis) en die koninkryk (basileia). Die fokus van die debat was op die vraag na legitieme heerskappy. In die post-Alexander era kon die model van die stadstaat nie meer effektief aangewend word nie, omdat die polis een van die meganismes vir kolonisasie, imperiale uitbreiding en die beheer oor ander volke en grondgebied geword het.

Die model wat oorgebly het, was dus dié van die basileia, en gevolglik het die debat verskuif na die vraagstelling oor legitimiteit van mag en voordele. Daar is al meer gefokus op die verskille tussen 'n koning en 'n tiran. Die ideale koning sou iemand wees wat met die hoogste etiese standaarde regeer het. Hiervan was daar in die werklike wêreld baie min sprake.

Gevolglik het was daar twee interessante wendings in die debat. Die een was 'n ontploffing van kreatiewe verbeelding, wat tot die daarstelling van mites gelei het. In sulke gevalle moes die ideale koninkryk "verbeel" word, wat op een of ander manier in verband gestaan het met die werklikheid. So is die verlede byvoorbeeld voorgehou as die goue era, die natuur is voorgestel as dat dit deur wetmatighede beheer is en die kosmos is gesien as ewige stad 
waarin alle mense gewoon het as kosmopoliete. Hoop op beter tye is gevoed deur projeksies van die ideale koninkryk wat in die toekoms sou aanbreek (Mack 1993:25-126).

Die ander wending het plaasgevind by die skole van populêre etiese filosowe. In 'n tydperk gekenmerk deur sosiale spanning en onsekerheid, wat veroorsaak is deur die afbreek van tradisionele sosiale strukture en die verplasing van mense buite die bekende strukture van die reg, het die model van basileia die metafoor geword vir persoonlike selfbeheer. Die term koning het nie meer die werklike persoon van die koning aangedui nie maar was die metafoor vir die mens in sy "hoogste" denkbare vlak van verwesenliking, sukses en etiese uitnemendheid. Koninkryk het nie meer verwys na die gebied waaroor geheers is nie, maar het die metafoor geword vir die soewereiniteit, vryheid, vertroue en selfbeheer van die superieure mens, die persoon met etiese integriteit wat sy eie wêreld koninklik kon regeer. Verder het die term basileia tou theou in die populêre filosofie voorgekom, veral by die Sinici se sosiale kontra-kulturele gedrag. Hulle aforistiese imperatiewe oor die basileia tou theou het 'n stellinginname jeens die lewe gevra, wat die basis kon vorm vir 'n alternatiewe sosiale etos en etiek vir mense wat op soek was na alternatiewe. Die moontlike vloei van konnotasie moet in gedagte gehou word wanneer die term basileia tou theou in $Q^{1}$ bestudeer word (Mack 1993:126-127).

Hierdie metaforiese aanwending van die basileia tou theou, wat 'n verandering weg van die "gewone" betekenismoontlikhede is, het ook te make met terapeutiese of helende funksie, waardeur 'n alternatiewe sosiale etos aangebied word vir mense wat vasgevang is in tye van onsekerheid en ingrypende veranderinge. Deur die gebruikmaking van 'n term soos basileia tou theou word mense gevra om 'n paradigmaskuif te ondergaan waardeur hulle die werklikheid herdefinieer. Dis 'n proses van heroriëntasie deur middel van disoriëntasie. Disoriëntasie kom neer op die erkenning van 'n gebrekkige siening van die werklikheid, waarna heroriëntasie volg, wat dan die aanvaarding van 'n nuwe denkwyse beteken (Borsch 1988:13-14). Disoriëntasie kan raakgesien word in metaforiese gebruik van basileia tou theou, deurdat die bekende betekenismoontlikhede verval en 'n vae nuwe en ideale betekenisveld open. Basileia tou theou as metafoor word nou simbool, aangesien die betekenis newelagtig is en nie spesifiek omskryf kan word nie. Dat die basileia tou theou "kan kom","verkondig", "aangekondig", en "bekendgemaak word", dui aan dat die betekenis diskongruent is met koningskap, omdat hierdie terme nie met koningskap assosieer word nie (Scott 1990:57). 


\section{Die $\mathbf{Q}^{1}$ gemeenskap as een van die grondtipes van die kerk in die Nuwe Testament}

Anders gestel: basileia tou theou word paradoksaal aangewend, waardeur terapeutiese moontlikhede geopen word, deurdat die idees van konvensionele wysheid verpletter word (Borg 1994:80-81). Stephen Lankton (aangehaal deur Davies 1995:133) wys daarop dat die paradoks eers mense herinner aan 'n denkwyse wat nie voorheen oorweeg is as oplossing vir die probleem voorhande nie. Tegelykertyd veroorsaak die paradoks 'n mate van verwarring deurdat die paradoks die bekende reëls van logika omverwerp. Logika word lamgelê en sodoende word die onbewuste geaktiveer om die nuwe betekenismoontlikheid te ondersoek. Die nuwe betekenismoontlikhede word deur die metafoor gestimuleer, aangesien dit die ooreenkoms aandui tussen sake wat verskillend voorkom. Die metafoor van basileia tou theou word in essensie ongedefinieerd gelaat sodat dit nie op rasionele vlak funksioneer nie, maar op die vlak van die onbewuste. Sodoende word toegang via die onbewuste verseker en vul elke indiwidu self die betekenis van die metafoor in. Daardeur verkry mense in die hede toegang tot die belewenis van die basileia tou theou en ondervind hulle psigologiese heling. Op hierdie manier word basileia tou theou uit die sfeer van die bo-natuurlike weggeneem en verplaas na die sfeer van die historiese en psigologiese werklikheid. Wanneer dit vir iemand gebeur, word basileia tou theou 'n verstaanbare en beleefde werklikheid (Davies 1995:134-136). Die proses waardeur dit plaasvind, kan psigologies verklaar word aan die hand van paradoksale terapie. Paradoksale terapie verander die betekenis van dit wat lyk na 'n outomatiese, onbeheerbare reaksie op 'n probleem, na 'n beheerbare reaksie juis deur die aanvanklike reaksie paradoksaal te bevestig en te versterk. So word iemand voor die bewuste keuse gestel om weer dieselfde reaksie te toon, maar dit anders te verstaan (Davies 1995:143-144). In die geval van $Q^{1}$ tekste sou die gewone reaksie van die $Q^{1}$ gemeenskap in die moeilike omstandighede en van die verstaan van hulle sending as Jesusbeweging, steeds wees dat hulle arm is, dat hulle onseker is oor die toekoms en oor hoe mense hulle gaan ontvang; dat hulle sou bid, dat hulle dinge sou nodig hê om hulle lewens in stand te hou en dat die beweging klein in getal is. Deur hierdie werklikhede paradoksaal te bevestig en dan in kombinasie met die metafoor van basileia tou theou te plaas, word die emosionele en konsepsionele betekenis wat voorheen aan die onderskeie sake gekoppel was, verander.

Dit kom daarop neer dat Jesus sy eie ervaring van geesvervuldheid gebruik om mense te begelei tot die verwante alternatiewe bewussynstoestand van basileia tou theou, deur hierdie metafoor te gebruik as primêre transaksionele (mitiese) simbool waaraan mense emosioneel verbind word (Davies 1995:145). Dit sou kon beteken dat die $Q^{1}$ gemeenskap hulle sending 
beskou het as om ander uit te nooi om te midde van pynlike en onseker omstandighede in die werklike wêreld, heling en beheer te ondervind deur deel te word van hierdie Jesusbeweging, wat die basileia tou theou verteenwoordig, en neerkom op 'n alternatiewe bewussynstoestand.

Die vraag is nou, indien die kerk sigself steeds as Jesusbeweging wil beskou, of hierdie helende aard van die Jesusbeweging as koninkryk van God nie ook verstaan behoort te word as 'n primêre kenmerk van die kerk nie. Dit sou impliseer dat die $Q^{1}$ gemeenskap as grondtipe van die kerk beskou kan word, hoewel hulle die heling nie in verband gebring het met Jesus se dood en opstanding en sy Messiasskap nie. In hierdie opsig is dit belangrik om in te sien dat Davies (1995:145) aandui dat Jesus se genesings te make het met vergifnis van sonde (wat gewoonlik verstaan word as die effek van Jesus se sterwe) en die terapeutiese aanwending van die begrip basileia tou theou. Op beide hierdie terreine het ons te make met helende aktiwiteit in die sosiale universum, wat nie verbind word aan Jesus se dood en opstanding as mitiese aspekte van 'n simboliese universum nie, maar met basileia tou theou as simboliese universum wat die basileia tou theou as sosiale sfeer van die $Q^{1}$ beweging oorspan en legitimeer. Van Aarde (2001:43) bring ook basileia tou theou in verband met die helende aard van Jesus se optrede. Jesus het 'n basileia tou theou voorsien wat nie primêr kataklismies sou wees, of vergelykbaar sou wees met enige aardse koninkryk waar menslikheid agter simbole van mag en hiërargie verdwyn nie. Die basileia tou theou kan eerder vergelyk word met 'n huishouding waar verwronge verhoudings genees word deur 'n etos van medelye ("ethos of compassion") en God se onmiddellike en onbemiddelde ("unmediated") teenwoordigheid.

Die mense van die eerste eeu se Mediterreense wêreld het 'n baie sterk godsdienstige bewussyn gehad en die sosiale wêreld is nie beskou as los te maak van die simboliese universum nie. In hierdie opsig was basileia tou theou die perfekte sfeer, die simboliese universum en verlengstuk van die sosiale wêreld. In hierdie verband het Jesus, anders as die apokaliptiese profete, nie ondraaglike omstandighede probeer ontsnap deur op futuristiese wyse in "verbeelde tyd" te ontsnap na God se sfeer nie. Jesus het God se teenwoordigheid ervaar te midde van en ten spyte van neerdrukkende omstandighede (Van Aarde 2001:44). Die Q1 gemeenskap, wat die Jesusbeweging is wat waarskynlik kronologies die naaste aan Jesus was waartoe ons toegang het, het deur hulle tekste en optrede iets hiervan weergegee te midde van hulle eie problematiese omstandighede deur hulle aanwending van en selfverstaan as basileia tou theou. 


\section{DIE “KONINKRYK VAN GOD” IN Q1 AS SIMBOLIESE EN SOSIALE UNIVERSUM}

Die sosiale leefwêreld van die eerste-eeuse Palestynse samelewing is oorspan deur 'n simboliese universum van konvensionele wysheid. Hierdie konvensionele wysheid kan beskryf word as die dominante bewussyn van enige kultuur. Dit is die mees algemeen aanvaarde idees oor hoe dinge daaruit sien, soos byvoorbeeld die wêreldbeeld. Dit is ook die algemeen aanvaarde idees oor hoe mense behoort op te tree. Dit is dus daardie kennis waarvan almal weet en waarin almal deur die proses van grootword gesosialiseer word.

It is a culture's social construction of reality and the internalization of that construction within the construction within the psyche of the individual ... [lt] creates a world in which we live. It constructs a world; indeed, it is the contruction. It is a domestication of reality, a net we cast over reality. It is basically life within the socially constructed world.

(Borg 1994:75, 77)

Lewe binne so 'n sisteem kan as baie beperkend beleef word, gekenmerk deur beperkte visie, beoordeling en meting van mense en optrede aan die hand van die kultuur. 'n Goeie voorbeeld hiervan is dat mense poog om binne hulle kultuur te presteer, wat op paradoksale wyse daarop neerkom dat hulle poog om "uit te staan" deur by uitstek te konformeer met die sosiale norme. In die konteks van die eerste eeu se Judaïsme was die konvensionele wysheid, wat die sentrale waardes van die kultuur verteenwoordig, voorsien deur die Torah en die volkswysheid aanwesig in die kultuur, soos byvoorbeeld verteenwoordig deur die boek Spreuke. Hierdie konvensionele wysheid het sosiale en sielkundige gevolge. Sosiaal beskou, skep dit 'n wêreld van hiërargieë en grense en op sielkundige vlak word dit die basis vir identiteit en selfagting. Jesus se woorde en optrede het neergekom op 'n ondermyning van die wêreld wat deur die konvensionele wysheid geskep is, deur 'n alternatief daar te stel. Die twee sake is intrinsiek onlosmaaklik: die eerste moet eers gedekonstrueer word sodat die tweede kan verskyn (Borg 1994:76$77,80)$.

Die ondermyning van die konvensionele wysheid veronderstel 'n alternatiewe wysheid. Bultmann (1963:69-108) het na aanleiding van sy vergelyking van Jesuslogia met die Ou-Testamentiese en Joodse mashal, tot die gevolgtrekking gekom dat Jesus ook as wysheidsleraar beskou kan word. Robinson het hierop voortgebou en die implikasie daarvan ondersoek dat 
Jesuslogia in Q as logia sophon verstaan word. Robinson het $Q$ op 'n wysheidstrajek geplaas wat strek vanaf die Ou-Testamentiese wysheid deur tot by die tweede eeu se Christelike wysheidskringe. Sedertdien is die internasionale aard van wysheidsliteratuur aangedui. $Q$ is ook vergelyk met nie-Joodse parallelle, veral uit Griekse filosofiese kringe, omdat $Q$ in Grieks geskryf was (Kloppenborg 1999:263). Wat genre betref, word die term logoi sophon nou deur vele as gepaste generiese aanduiding van $Q$ aanvaar, ten spyte van die feit dat $Q$ saamgestel word uit chriae, profetiese en apokaliptiese logia en die versoekingsberig (Kloppenborg 1999:30-31). Kloppenborg (1999:144) het daarop gewys dat die $Q^{1}$ laag hoofsaaklik wysheidsmateriaal bevat het: "... a collection of sapiental speeches and admonitions was the formative element in Q."

Die aforismes van $Q^{1}$ handel oor temas wat mense uitgenooi het tot ' $n$ spesifieke alternatiewe visie op die werklikheid en andersoortige lewenswyse (Borg 1994:70-71). Dit kan beskryf word as soortgelyk aan dit wat populêre filosowe van die hellenistiese en Grieks-Romeinse tydperke voorgehou het. $Q^{1}$ weerspieël 'n praktiese etiek van die tyd wat alom as die Siniese filosofie bekendgestaan het. Die sorgvuldige samestellings van die chriae versamelings in $Q$ benut literêre tegnieke van selfs hoër gehalte as bekende Siniese werke soos Demonax en die Diogenes chriae en nader aan die vlak van $m$. 'Abot (Kloppenborg 1999:310-316). Dit dui daarop dat Jesus deur die geloofsgemeenskap agter $Q^{1}$ beskou was as 'n leermeester in die Siniese styl. Crossan beskryf Jesus daarom as "a peasant Jewish Cynic" (Crossan 1992:421). Die rol en spreekwyse van die Siniese filosowe stem tot 'n groot mate ooreen met die van die Ou-Testamentiese profete, naamlik as kritici van die konvensionele waardes en magsmisbruike van hulle tyd (Borg 1987:11516; Mack 1993:114-115).

Die geloofsgemeenskap van $Q^{1}$ was 'n Galilese gemeenskap in die tydperk voor die vernietiging van Jerusalem en die tempelstaat wat, soos die res van die Galilese bevolking, gedurende die Hellenistiese en Romeinse eras die politieke magsverskuiwings oor hulle grondgebied moes verwerk (Crossan 1992:17-19). Die gebruiklike strategieë was nie meer voldoende om die magsaansprake van vreemde konings, priesters en generaals, asook die algemene gevoel van onsekerheid en onveiligheid te hanteer nie. Die Siniese filosofiese benadering was handig om midde in die Galilese omstandighede sosiale kritiek te lewer. So het die $Q^{1}$ gemeenskap, teen die agtergrond van die kulturele diversiteit van Galilea ( $\mathrm{vgl}$ argeologiese fondse bespreek deur Crossan \& Reed 2001:136-176), die gesag van enige kultuur bevraagteken wat aanspraak gemaak het om die standaard vir ander kulture te stel. Hulle het mekaar aangemoedig om 'n lewe van eenvoud te volg. "The Jesus 


\section{Die $Q^{1}$ gemeenskap as een van die grondtipes van die kerk in die Nuwe Testament}

movement began as a homegrown variety of Cynisism in the rough and ready circumstance of Galilee before the war" (Mack 1993:119-120.)

Vanuit die $Q^{1}$ laag, kan die volgende afleidings oor die $Q^{1}$ gemeenskap gemaak word (Mack 1993:120): geloofstellings was nie so belangrik as die regte optrede binne die publieke arena nie. Die sosiale sfeer was nie soseer onderwerp aan sosiale analise, ten einde die oorsake van euwels aan te dui nie. Die bedoeling van die beweging was ook nie om die breë sosiale gemeenskap te hervorm nie, maar om indiwidue juis aan te moedig om nie volgens die aanvaarde reëls van die samelewing op te tree nie. Gedrag wat aangemoedig was, was doelbewus onkonvensioneel, matig afbrekend en implisiet kontra-kultureel. Dit is van kardinale belang om raak te sien dat daar geensins gebruik gemaak is van 'n eksterne of institusionele bedreiging om die verandering in leefwyse te motiveer nie. Daar was geen plan om die Romeinse mag te beveg of die Joodse godsdiens te hervorm nie.

Vanweë 'n duidelike sosiale visie het die beweging positiewe reaksie ontlok en eendersdenkende mense het by die beweging aangesluit. Algaande is die tekste meer verstaan as en omvorm tot riglyne wat normatief vir die groep behoort te wees (vgl Crossan \& Reed 2001:160-173 oor heling, maaltye, rondreisende ingesteldheid, reinheid en gemeensaamheid). Aangesien die Siniese filosowe juis nie daarvoor bekend was dat hulle by bewegings aangesluit het wat tot sosiale groepvorming gelei het nie, kom die Siniese analogie hiermee tot 'n einde. Die tekens van sosiale groepvorming op die eerste stadium van $Q^{1}$ komposisie, is die volgende (Mack 1993:121):

- Die verskuiwing weg van aforismes na stelreëls in die vorm van die leuses of spreuke;

- die hoë voorkoms van imperatiewe;

- die gebruik van tweede persoon persoonlike aanspreekvorm;

- groter belangstelling in die meebring van 'n uitdagende aanspraak met betrekking tot die gehalte van menslike verhoudings;

- $\quad$ klem op 'n meer egalitêre siening van sosiale rolle en hiërargie.

Hierdie tekens van sosiale groepvorming is tegelyk die eerste treë in die vorming van 'n simboliese universum wat die sosiale universum van die groep sal legitimeer. Simboliese universums kan beskryf word as ... bodies of theoretical tradition that integrate different provinces of meaning and encompass the institutional order in a symbolic totality ... (Berger \& Luckmann 1975:113).

Die noue verbondenheid van die sosiale universum (die sfeer van die daaglikse ontmoetings van aangesig tot aangesig) en die simboliese universum bestaan daarin dat die oorsprong van die simboliese universum 
enersyds in die sosiale universum geleë is, en andersyds dat die simboliese universum as hoogste vlak van legitimering vir die sosiale universum dien (Petersen 1985:27). Die beweging na stelreëls en imperatiewe is aanduiding van teoretisering oor die betekenisnuanses van deel te wees van hierdie Jesusbeweging, dus van die aanvang van die daarstelling van 'n simboliese universum.

Die tweede stadium van $Q^{1}$ komposisie dui op verdere groepvorming, naamlik 'n groter klem op deelwees van die beweging en 'n sosiale visie (Mack 1993:121-122). Imperatiewe in die vorm van die vroeëre aforistiese styl word omvorm tot reëls vir die groep en word met argumente gestaaf. Nuwe idees en soorte van diskoers kom na vore ten einde die etos van die groep te ondersteun. Veral belangrik is die volgende:

- die verwysing na die koninkryk van God (basilea tou theou);

- die appèl op die natuur as manifestering van die goddelike;

- die gebruik van voorbeelde uit die epiese geskiedenis van Israel.

Hierdie kenmerke dui aan dat refleksie oor die beweging plaasgevind het en dat 'n manier gevind is om 'n beredeneerde verslag te kan gee van die groep se oortuigings, wat vir ander vreemd kon klink.

Dit dui volgens my egter ook ' $n$ verdere ontwikkeling in die daarstelling van 'n simboliese universum aan, veral wat betref die gebruik van die term "koninkryk van God". "Koninkryk van God" (basilea tou theou) is die enigste term in $Q^{1}$ waarmee die geloofsgemeenskap aangedui word. Met "koninkryk van God" word die gesag van God om te regeer of te oordeel aangedui, sowel as 'n sfeer of gebied waar hierdie heerskappy van God volledig geaktualiseer word. Dit is juis hierdie heerskappy van God wat deur die $Q^{1}$ gemeenskap verteenwoordig is (Mack 1993:123), maar ook die gesag waaronder hulle staan. Hierdie term verteenwoordig dus die sosiale universum van die $Q^{1}$ groep, wat hulleself met die term beskryf. Ter selfdertyd word hierdie term ' $n$ aanduiding van die simboliese universum wat die sosiale wêreld van die groep oorspan en legitimeer.

Eienskappe van die gemeenskap wat hulleself (sosiale en tegelyk simboliese universum) aangedui het as basileia tou theou, was dat hulle baie arm was en moes bedel ("destitute") ( $n$ a v die saligspreuk oor die armes) (QS 8), onaanvaarbaar/verwerp was ("undesirables") ( $\mathrm{n}$ a $v$ die verwysing na die koninkryk as mosterdsaad (onwelriekende struik wat maklik vervuil), en suurdeeg (wat die algemene simbool was van morele verval) (QS 46), 'n vorm van liturgie gehad het ( $\mathrm{n}$ a $v$ die bede vir die koms van die basileia en daaglikse brood) (QS 26) (Crossan 1992:265-302). 


\section{Die $Q^{1}$ gemeenskap as een van die grondtipes van die kerk in die Nuwe Testament}

Aan die een kant dui die $Q^{1}$ groep dus hulleself as sosiale verskynsel met die term aan. Aan die ander kant dien die term reeds as objektivering en legitimering van die groep, in die sin van 'n simboliese universum wat subversief is jeens die bestaande aanvaarde wysheid as sosiaal aanvaarde simboliese universum. Dit mag vreemd voorkom dat dieselfde term tegelyk aanduiding is van die sosiale en simboliese universums. Die sosiale universum, aangedui deur die term "koninkryk van God", dien as oorsprong van die simboliese universum, wat met dieselfde term aangedui word. Dit kan soos volg verklaar word: die sosiale orde is 'n produk van menslike aktiwiteit, wat aan die een kant die gevolg is van mense se voortgaande eksternalisering van hulleself, maar aan die ander kant 'n werklikheid is wat die individue voorafgaan en wat hulle konfronteer as 'n werklikheid buite hulleself. Deur die proses van objektivering word die wêreld wat deur die mens geskep is, getransformeer: "The humanly produced world becomes something 'out there'. It consists of objects, both material and non-material, that are capable of resisting the desires of their producer .... It stands outside the subjectivity of the individual as, indeed, a world" (Berger 1973:18-19).

Die feit dat term "koninkryk van God" vir beide die simboliese as sosiale universums gebruik word, kan myns insiens ook 'n aanduiding wees dat die term dui op die wesenlike kenmerk van die betrokke gemeenskap.

\section{BEVINDING}

Indien die geykte kenmerke van die Christelike kerk gebruik word, kan die $Q^{1}$ gemeenskap sekerlik nie as "Christelik" of "kerk" beskryf word nie. Uit die tekste blyk dit dat hulle nie die dood en opstanding van Jesus as verlossingsgebeure beskou het of as manier om toegang tot die koninkryk van God te verkry nie. Hulle tekste het ook nie oor Jesus as die Christus gepraat nie.

Ek is egter van mening dat die redenasie omgekeer behoort te word. Indien die vroegste tradisie wat ons oor Jesus het, 'n ander kenmerk of kenmerke as wesenlik geag het en Jesusstudies aandui dat Jesus dit waarskynlik ook gedoen het, is die vraag of ons nie eerder van die Christelike kerk moet vra om ook aan hierdie kenmerk(e) te voldoen nie, ten einde 'n Jesusbeweging in die ware sin van die woord te wees nie.

Die vraag is ook of ons nie reeds in die Nuwe Testament, ten spyte van die ontwikkelingsgang en uiteenlopendheid van die dokumente, ooreenkomste kan vind met Jesus en die $Q^{1}$ gemeenskap se aanwending van basileia tou theou nie. Een so 'n voorbeeld is die apostel Paulus. Wanneer hy verduidelik wie tot die ware "Israel van God" behoort, gebruik hy die metafore van familie en aanneming tot kinders van God (Rom 8). Hiermee kontinueer 
Paulus die hart van Jesus se boodskap oor kinders wat die koninkryk van God binnegaan (Van Aarde 2001:176).

Hierdie kontinuïteit is merkwaardig, omdat Paulus op die gekruisigde en opgestane Jesus gefokus het. Petrus, daarenteen, was 'n vertrouelinge en metgesel van Jesus tot met sy arrestasie. Dit is daarom ironies dat Paulus, eerder as Petrus, die hart van Jesus se boodskap verstaan en oorgedra het (Funk, in Van Aarde 2001:178). Net so ironies sou dit wees indien die essensie van basileia tou theou, as heel basiese kenmerk van die oudste Jesusbeweging, nie ook as wesenlike kenmerk van die Christelike kerk onderskei word nie.

Die $Q^{1}$ gemeenskap kan myns insiens beskou word as grondtipe van die kerk. Hierdie gemeenskap bevraagteken via tekste die kerk steeds na die mate waarin die kerk uitdrukking is van die basileia tou theou as essensiële kenmerk van 'n Jesusbeweging. Is die wesenlike van die kerk steeds 'n etos van medelye en onbelemmerde toegang tot God waar heling van verhoudings plaasvind, te midde van 'n wêreld vol magsmisbruik, onsekerheid en onveiligheid? Is dit wat basileia tou theou verteenwoordig die kern van die kerk se selfverstaan? Wat dan van postmoderne mense wat nie die dood en opstanding van Jesus as verlossingsgebeure aanvaar nie, en Jesus ook nie as Christus bely nie, maar tog deel wil wees van die koninkryk van God, lidmate wil wees van die kerk omdat hulle medelye voorstaan en die heling van verhoudings wil beleef te midde van die onbelemmerde toegang tot God? Beskik hulle nie dalk oor een van die wesenlike vereistes vir lidmaatskap van 'n ware Jesusbeweging nie? Behoort hulle gebrek aan "Christelike geloof" hulle summier van lidmaatskap van die kerk te diskwalifiseer?

Ek stem met Käsemann (1964:262) saam, naamlik dat ons nie in die in die Nuwe-Testamentiese dokumente sprake het van 'n ekklesiologie nie. Ek meen wel dat dit wat uiteindelik die kern van 'n ekklesiologie moet wees, naamlik die basileia tou theou, soos reeds by die $Q^{1}$ teks aanwesig is, steeds vandag die essensie van die ekklesiologie behoort te wees. Dit sal moontlik wees indien die kerk vandag nie 'n apokaliptiese simboliese universum huldig nie, maar juis die van basileia tou theou. Indien daar met oortuiging hieraan vasgehou word as essensie van die kerk, behoort die sosiale werklikheid van die kerk daarvan te getuig. Wanneer dit gebeur sal die kerk die basileia tou theou verteenwoordig met 'n etos van medelye en die heling van verwronge verhoudinge bring deur die onbelemmerde toegang tot God te verkondig. 


\section{Die $Q^{1}$ gemeenskap as een van die grondtipes van die kerk in die Nuwe Testament}

\section{Literatuurverwysings}

Bauer, W 1972. Orthodoxy and heresy in earliest Christianity. London: SCM.

Berger P L 1973. The social reality of religion. Harmondsworth: Penguin.

Berger, P L \& Luckmann, T 1975. The social construction of reality: A treatise in the sosiology of knowledge. Harmondsworth: Penguin.

Borg, M J 1994. Meeting Jesus again for the first time: The historical Jesus and the heart of contemporary faith. San Francisco, CA: Harper.

Borg, M J 1987. Jesus: A new vision. Spirit, culture and the life of discipleship. San Francisco, CA: Harper.

Borsch, F 1988. Many things in parables. Philadelphia, PA: Fortress.

Bultmann, R K 1963. The history of the synoptic tradition. Oxford: Blackwell.

Bultmann, R K 1980. Theologie des Neuen Testaments. Tübingen: Mohr.

Crossan, J D 1992. The historical Jesus: The life of a Mediterranean Jewish peasant. San Francisco, CA: Harper.

Crossan J D \& Reed J L 2001. Excavating Jesus: Beneath the stones, behind the texts. San Francisco, CA: Harper.

Davies, S L 1995. Jesus the healer: Possession, trance and the origins of Christianity. London: SCM.

Funk, R W 1996. Honest to Jesus: Jesus for a new millennium. San Francisco, CA: Harper.

Käsemann, E [1951] 1960. Begründet die neutestamentliche Kanon die Einheit der Kirche?, in Exegetische Versuche und Besinnungen, I, 214-223. Göttingen: Vandenhoeck.

Käsemann, E 1964. Einheit und Vielfalt in der neutestamentliche Lehre von die Kirche, in Exegetische Versuche und Besinnungen, II, 262-267. Göttingen: Vandenhoeck.

Kloppenborg, J S 1999. The formation of Q: Trajectories in ancient wisdom collections. Studies in antiquity and Christianity. Harrisburg, PA: Trinity.

Kümmel, W G 1980. The theology of the New Testament according to its major witnesses Jesus - Paul - John. London: SCM.

Lankton, S 1991. Ericsonian styles of paradoxical therapy, in Weeks, G (ed), Promoting change through paradoxical therapy. New York: Brunner.

Lohse, E 1979. Grundriss der neutestamentlichen Theologie. Stuttgart: Kohlhammer.

Louw, J P \& Nida, E A 1993a. Greek-English Lexicon of the New Testament based on semantic domains, Vol 1: Domains. Cape Town: United Bible Society.

Louw, J P \& Nida, E A 1993b. Greek-English Lexicon of the New Testament based on semantic domains, Volume 2: Indices. Cape Town: United Bible Society.

Mack, B L 1993. The lost gospel: The book of $Q$ and Christian origins. San Francisco, CA: Harper.

Pelser, G M M 1994. Enkele opmerkings oor die wese van die kerk, HTS 50, (1\&2), 311-329.

Pelser, G M M 1995. Die kerk in die Nuwe Testament, HTS 51(3), 645-676.

Petersen, N R 1985. Rediscovering Paul: Philemon and the sosiology of Paul's narrative world. Philadelphia, PA: Fortess.

Robinson J M, Hoffmann, P \& Kloppenborg, J S (eds) 2000. The critical edition of Q. Minneapolis, MN: Fortress. (Hermeneia.) 
Scott, B B 1990. Hear then the parable: A commentary on the parables of Jesus. Minneapolis, MN:Fortress.

Van Aarde, A G 2001. Fatherless in Galalee: Jesus as child of God. Harrisburg, PA: Trinity.

Weeks, G (ed) 1991. Promoting change through paradoxical therapy. New York: Brunner. 